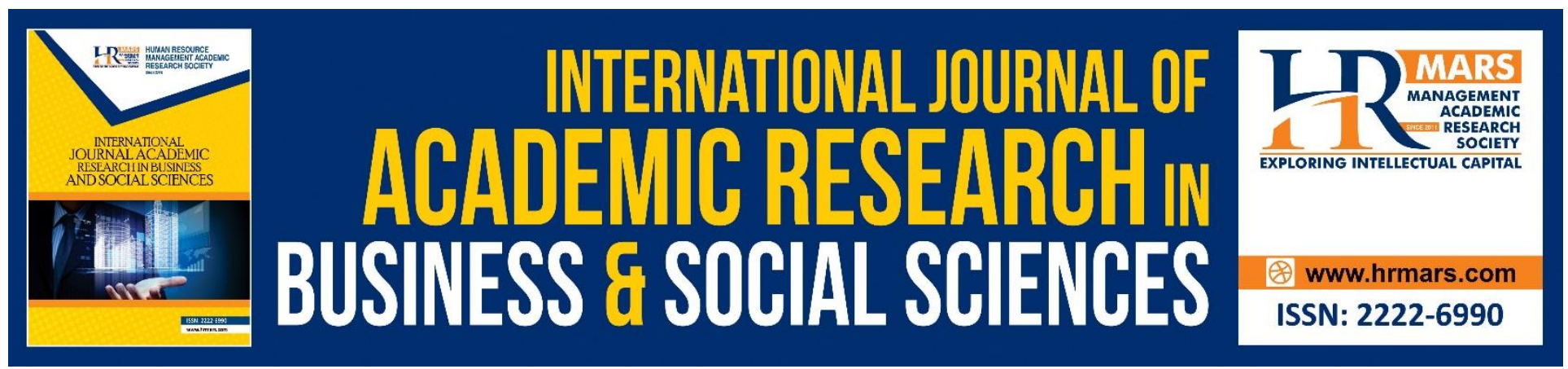

\title{
Factors Affecting the Readiness of Using AutoCAD Software in Teaching
}

\section{Zuraifah Safiee, Zaliza Hanapi, Yong Seh Sheh}

To Link this Article: http://dx.doi.org/10.6007/IJARBSS/v9-i5/5845

DOI: $10.6007 /$ IJARBSS/v9-i5/5845

Received: 22 Feb 2019, Revised: 12 March 2019, Accepted: 30 April 2019

Published Online: 23 May 2019

In-Text Citation: (Safiee, Hanapi, \& Sheh, 2019)

To Cite this Article: Safiee, Z., Hanapi, Z., \& Sheh, Y. S. (2019). Factors Affecting the Readiness of Using AutoCAD

Software in Teaching. International Journal of Academic Research Business and Social Sciences, 9(5), $128-137$.

Copyright: (C) 2019 The Author(s)

Published by Human Resource Management Academic Research Society (www.hrmars.com)

This article is published under the Creative Commons Attribution (CC BY 4.0) license. Anyone may reproduce, distribute, translate and create derivative works of this article (for both commercial and non-commercial purposes), subject to full attribution to the original publication and authors. The full terms of this license may be seen

at: http://creativecommons.org/licences/by/4.0/legalcode

Vol. 9, No. 5, 2019, Pg. 128 - 137

http://hrmars.com/index.php/pages/detail/IJARBSS

JOURNAL HOMEPAGE

Full Terms \& Conditions of access and use can be found at http://hrmars.com/index.php/pages/detail/publication-ethics 


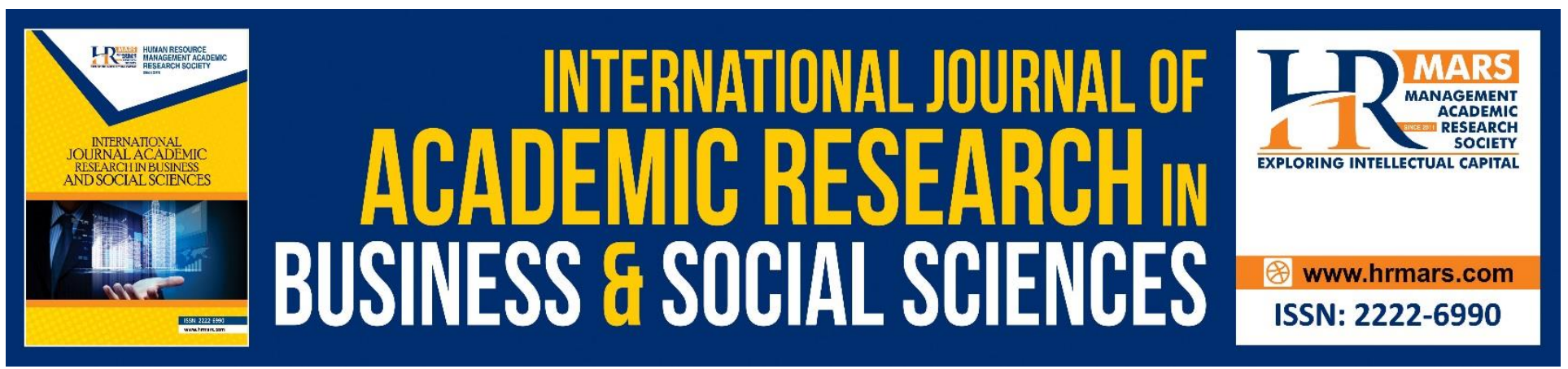

\title{
Factors Affecting the Readiness of Using AutoCAD Software in Teaching.
}

\author{
Zuraifah Safiee, Zaliza Hanapi, Yong Seh Sheh \\ Department of Engineering Technology, Faculty of Technical and Vocational, \\ Universiti Pendidikan Sultan Idris, 35900 Tanjong Malim, Perak, Malaysia
}

\begin{abstract}
Technical and Vocational Education (TVE) is an important path for the development of vocational education skills itself. The implementation of the Vocational College Standard Curriculum (VCSC) at a Vocational College (VC) is a major challenge to the teaching staff involved. One of the courses offered in the program of Construction Technology is Computer-Aided Design (CAD) program which requires the use of AutoCAD software in the process of drawing. The almost non-existence or the unavailability of the textbooks for referrals makes it hard and difficult for most of the non-option teachers to find the direction of teaching that they want to deliver. Therefore, this research was conducted to identify the level of readiness of using the AutoCAD software among the Construction Technology educators at vocational colleges (CV) throughout Peninsular Malaysia. The research methodology used in this study is by reviewing past studies or literature reviews. The results show that there are four main factors that contributed to the level of readiness which is the knowledge, skills, attitudes, and training. In this regard, this research will also explain the details pertinent to the factors that affect the readiness of using AutoCAD software among the Construction Technology educators at vocational colleges. Through the results of this research, it is hoped that it can provide further insight for the Technical and Vocational Education Division (TVED) to develop and produce an initial course for all VC's educators, which is in line with the latest technology before the implementation of any new program is carried out.
\end{abstract}

Keywords: AutoCAD, Construction Technology, Education, Vocational College

\section{Introduction}

The United Nations Educational, Scientific and Cultural Organization (UNESCO) define TVE as a field involving all aspects of the educational process, in addition to general education, related technological and scientific studies and the acquisition of practical skills, attitudes, understanding and work-related knowledge in various sectors of economic and social life (Kementerian Pendidikan Malaysia, 2015). The implementation of the Vocational College Standard Curriculum (VCSC) at a Vocational College (VC) is a major challenge to the teachers involved. It is unavoidable that all the Vocational College's teaching staff needs to increase 
their values and importance that is in line with the implementation of the VC's curriculum. One of the skills required for Vocational College educators is the skills of using AutoCAD software. This software is used through the method demonstration in the process of teaching and facilitating (TnF) to complete the module, which requires the students to generate designs related to the buildings as contained in the established curriculum.

The use of this software is also a necessity in the construction of practical question and theoretical items that involve diagrams. According to Aris (2001), to master the field of Information Technology and Telecommunications, one should first identify the main elements that helps to develop it. Badri, Al Rashedi, Yang, Mohaidat and Al Hammadi (2014) reckons that in order to comprehend and turning the potential benefits of the Information and Communications Technologies (ICT) into reality, it is important that school teachers receive new technology integrations in the settings of their teaching practices. In the context of this research, the mastery and acceptance of knowledge and skills regarding the use of AutoCAD software will make the educators more willing and prepared to carry out the TnF process.

With the implementation of the Computer-Aided Design (CAD), which requires the use of AutoCAD software in producing drawing or designs, it has become a challenge for the educators of the Construction Technology program. The absence of textbooks for referrals cause most of the nonoption teachers having difficulty to find the direction of the teaching that they want to convey. The teachers also felt that they are not competent enough if they cannot spontaneously or immediately answer questions from students.

Other than that, a learning module also needs to be formulated personally by the teachers based on the provided Vocational College Standard Curriculum (VCSC) as a syllabus. Due to this matter, the teachers cannot ensure that the content of the self-sufficient lesson is adequate to determine the student's competency for their future career. A study conducted by Azizah (2016) on the non-option teachers, suggests that the readiness of the non-option teachers that teach in VC is at a moderately high level in terms of the knowledge, skills and attitudes. This situation will not happen if they can master the lesson that will be shared with the students.

If other aspect is taken into a discussion, training is one of the important strategies in the organizations to help increase the knowledge and skills of the employees that are relevant to the needs of the organization. This had been acknowledged by Simona (2015), which revealed the importance of the teacher training, which is to instill true skills into the teaching of their respective fields of expertise. A one-week training period is seen to be insufficient to make a teacher fully mastering the content of the theoretical lesson, not to mention when it involves a lesson that needs skill activities. There are even teachers who do not have the opportunity to attend the courses due to the time constraints that is filled with the extremely crowded activities.

Hence, the researcher feels that this research should be carried out to examine the readiness of the teachers to use the AutoCAD software in the process of TnF. The readiness that includes the aspects of the knowledge, skills, and attitudes will determine the success of a TnF session. In addition, this study can analyze the training needs by the educators of the Construction Technology based on their readiness. 
The Program of Construction Technology at VC offers a Computer-Aided Design (CAD) course (WTP6033) on the second semester of the Diploma in Construction Technology. Among the topics contained in the syllabus and require the use of AutoCAD software is Orthographic Projection, Architectural Drawing, Structural Drawing and Mechanical and Electrical Drawing (BPTV Curriculum Division, 2017). Hence, the teachers involved in teaching this course should have an in-depth knowledge and skills in using AutoCAD software. Additionally, the teachers must be positive and accept this educative task with an open heart and constantly strive to increase the knowledge and skills for them to always be ready and full of preparation before starting the TnF session.

The most important thing to be aware of before a teacher enters the classroom to begin the TnF session is their readiness and preparations. A study conducted by Izzati (2013) on the readiness of the vocational teachers who implemented the 'School Enterprise' Program in secondary school, found that the success of this program depends on the quality and the preparations made by the teachers from various aspects such as program knowledge, program management skills and attitudes to implement the program. If the opposite occurs, then the program fails to execute properly. This statement is in line with Kariyev, Turganbayeva, and Slambekova (2015) research in Kazakhstan. Through their research, they stated that the readiness of teachers to learn something is a condition for the students to develop their creative abilities, as it relies on the strength and professional structure of the teacher's own motivation. This will ultimately contribute to the readiness of teachers to face something new.

Suriana (2012) in her research explains that teachers as educators should equip themselves with all aspects of the knowledge, skills, attitudes, and emotions. This statement is collateral with the stance made by Zaiha (2014) which explains that teachers do not only need the knowledge and skills in teaching but they also need to have a good nature and a personality that can be set as an example and followed by their students.

\section{Knowledge}

The knowledge of a teacher is associated with the pedagogical knowledge possessed by the teacher in relation to a particular field he or she has mastered. Mastery of knowledge is very important as the teachers can determine the appropriate delivery technique to be easily understood by the students Khadijah (2013) research found that potential teachers for "Reka Cipta" subject are ready to teach when their level of knowledge and skills are high. Kopsen and Anderson (2017) in their research in Sweden found that with the reformation of the Swedish Vocational Education, it required the teachers to equip themselves with the knowledge and comprehension regarding work scopes that relates to their vocational subjects in an effort to strengthen lifelong employment. Other than that, the research conducted by Zarina (2016) regarding the level of knowledge readiness and the level of teachers training that is needed when applying high level thinking skills in TnF, indicates the aspect of knowledge readiness among the teachers with more experience compared to those with less experience. 


\section{Skills}

The offering of skills courses such as at VC requires highly skilled educators in every field being represented. Roslan (2014) argues that the need to master the knowledge of teaching skills, profound knowledge about the content of teaching and the attitude of a teacher seen during class and beyond the teaching time should be mastered so that the teaching and learning process can be delivered more effectively. This statement is supported by Jaafar (2014) in his study on the competency of VC educators, which stated that the theoretical proficiency alone is insufficient in order to produce skilled students. The teachers need to have the technical skills to facilitate their practice in teaching and learning.

Therefore, the importance of having a teacher's skill is seen as having the same degree of importance as having the knowledge about their teaching field. The research that had been conducted in Indonesia by Rohayani, Kurniabudi, and Sharipuddin (2015) regarding e-learning at the higher education center, found that besides attitudes, skills are the most important factor in establishing elearning readiness. They further added that each institution has a different level of readiness. Hence, each institution needs to be more careful in determining the critical factors that need to be focused on when measuring their e-learning readiness. This is to obtain accurate information that illustrates the real state of their institutions. This is in line with the research conducted by Pillai and Shaji (2017) in India, who found that vocational educators need to have basic engineering skills and pedagogical skills to be the best presenters and communicators infront of the students. They also need professional skills in both fields, as skilled workers and as educators. He concludes that vocational teachers need to improve their teaching skills and technical skills to recognize what is important for students so that they can motivate students to learn.

\section{Attitudes}

A positive attitude can be a catalyst for readiness and ultimately contribute to the effectiveness of TnF. Research conducted by Yagcı, Sırakaya, and Özüdoğru (2015) regarding web-based learning among prospective teachers in Turkey have found that there is no difference in attitude between the new teachers and long-service teachers. However, there are differences in readiness between the two groups. This explains that attitude is not influenced by how long a person engages in the education field.

Furthermore, positive attitudes are one of the things that a teacher needs to have when teaching in the workshop. Positive teachers are always confident and do not give up on their TnF. This statement is supported by the research of Izzati (2011) on Life Skills subject teachers, who found that the level of confidence in theoretical and practical aspects and the attitudes of the option teachers was higher than non-option teachers. Her research also found that the level of teacher's confidence in the theoretical and practical aspects was at a moderate level, and the attitude of the teachers was high on the teaching of life skills. This shows that attitude is influenced by the existing elements of the theoretical and practical knowledge as well as the self-confidence of a teacher.

However, this situation is different if they look from a positive point of view by constantly striving to strengthen their existing knowledge and thus increase their confidence level. This statement agreed with Izzati's (2013) opinion, which suggests that one's willingness depends on his attitude. If the teacher has positive attitudes, the probability of a teacher's success in performing a program is high. 
INTERNATIONAL JOURNAL OF ACADEMIC RESEARCH IN BUSINESS AND SOCIAL SCIENCES

Vol.9, No.5, May, 2019, E-ISSN:2222-6990 @ 2019 HRMARS

\section{Training}

Essentially, with sufficient training it can help to increase a teacher's self-confidence level towards his or her ability. Simona (2015) in his research in Romania found that vocational teachers required practical training in order to enhance their self-esteem and to be able to provide individual support to disadvantaged students, primarily related to the communication, problem solving, literacy, attitudes and endurance. He added that training programs should focus on assisting teachers to develop positive attitudes in themselves as well as students regarding employment, entrepreneurial skills, and job skills.

In addition, the use of technology in teaching requires specialized training as a preparation before starting the TnF session. According to Bonanno (2011), teachers play a major role to integrate learning technology in the educational process and in promoting the transformation of this curriculum. In the culture of knowledgeable community and with the emergence of new technologies, undeniably, the guidelines for the latest teaching methods are needed as well as a new approach in the teacher training process. It is clear that the use of technology in teaching will require the teachers to receive special training in order to be a good facilitator for students later on.

Additionally, in another perspective, experience can help to improve confidence levels and helps the teachers be more prepared Zarina (2016) found that the training requirements for experienced teachers were less compared to the least experienced teachers. Experienced teachers are certainly aware of the subject being taught. This finding is in line with Johar (2016) where there is a significant difference between the elements of the In-service Training required by teachers based on their experience in service. Experienced teachers need less training than new teachers. This clearly shows that the experience contributes in making an individual more mature and becoming more understanding of the things that happened through a certain period. The longer the duration, the more mature and proficient the teacher is.

In conclusion, based on the literature reviews, past studies and references made to the syllabus, there are four identified factors that need to be mastered by the teachers to ensure the readiness of using the AutoCAD software in teaching. 
INTERNATIONAL JOURNAL OF ACADEMIC RESEARCH IN BUSINESS AND SOCIAL SCIENCES Vol.9, No.5, May, 2019, E-ISSN:2 $222-6990$ ㄷ 2019 HRMARS

Table 1. The Factors that Effecting the Readiness.

\begin{tabular}{|c|c|c|}
\hline Factor & Item & Details \\
\hline \multirow{15}{*}{ Knowledge } & K1 & Basic instructions of AutoCAD software. \\
\hline & $\mathrm{K} 2$ & Functions of icons used in the AutoCAD software. \\
\hline & K3 & Use basic AutoCAD instructions to draw Orthographic Illustrations. \\
\hline & K4 & Draw symbols in architectural drawings using AutoCAD software. \\
\hline & K5 & Draw a location plan using AutoCAD software. \\
\hline & K6 & Interpret the layout of the buildings. \\
\hline & K7 & Draw the outlook design using AutoCAD software. \\
\hline & K8 & Draw a sectional view using AutoCAD software. \\
\hline & K9 & Draw a detailed drawing of the building using AutoCAD software. \\
\hline & K10 & Draw a symbol for the structural drawing using AutoCAD software. \\
\hline & K11 & Interpret the elements of the structural drawing for buildings more than one level. \\
\hline & K12 & Provide notes and teaching aids on the topics related to AutoCAD. \\
\hline & K13 & $\begin{array}{l}\text { Provide questions on AutoCAD related topics for student learning assessment } \\
\text { purposes. }\end{array}$ \\
\hline & K14 & $\begin{array}{l}\text { Make an analysis of student achievement on AutoCAD related topics according to the } \\
\text { predetermined level. }\end{array}$ \\
\hline & K15 & Handle the equipment and the teachings aids to facilitate TnF related to AutoCAD. \\
\hline \multirow{14}{*}{ Skills } & S1 & Basic instructions of AutoCAD software. \\
\hline & $\mathrm{S} 2$ & Functions of icons used in the AutoCAD software. \\
\hline & S3 & Use basic AutoCAD instructions to draw Orthographic Illustrations. \\
\hline & S4 & Draw symbols in architectural drawings using AutoCAD software. \\
\hline & S5 & Draw a location plan using AutoCAD software. \\
\hline & S6 & Interpret the layout of the buildings. \\
\hline & S7 & Draw the outlook design using AutoCAD software. \\
\hline & S8 & Draw a sectional view using AutoCAD software. \\
\hline & S9 & Draw a detailed drawing of the building using AutoCAD software. \\
\hline & S10 & Draw a symbol for the structural drawing using AutoCAD software. \\
\hline & S11 & Interpret the elements of the structural drawing for buildings more than one level. \\
\hline & S12 & $\begin{array}{l}\text { Draw a detailed drawing elements such as the foundation for a building more than one } \\
\text { level using AutoCAD software. }\end{array}$ \\
\hline & S13 & Provide teaching aids for AutoCAD related topics. \\
\hline & S14 & $\begin{array}{l}\text { Provide questions on AutoCAD related topics for student learning assessment } \\
\text { purposes. }\end{array}$ \\
\hline \multirow{7}{*}{ Attitudes } & A1 & $\begin{array}{l}\text { Plan suitable and appropriate teaching strategies to help enhance student's } \\
\text { understanding regarding the use of AutoCAD software. }\end{array}$ \\
\hline & A2 & $\begin{array}{l}\text { Provide the paperwork to make it easier for students to understand the contents that } \\
\text { are related to the use of AutoCAD software. }\end{array}$ \\
\hline & A3 & $\begin{array}{l}\text { Use a method of demonstration to deliver the lesson content regarding the use of } \\
\text { AutoCAD software to the students. }\end{array}$ \\
\hline & A4 & $\begin{array}{l}\text { Attend short courses in order to develop and generate more understanding regarding } \\
\text { the use of AutoCAD software. }\end{array}$ \\
\hline & A5 & $\begin{array}{l}\text { Refer and discuss with other educators to help increase their knowledge regarding the } \\
\text { use of AutoCAD software. }\end{array}$ \\
\hline & A6 & $\begin{array}{l}\text { Try to obtain reference materials for a wider information and more understanding } \\
\text { regarding the use of AutoCAD software. }\end{array}$ \\
\hline & A7 & $\begin{array}{l}\text { Guide the students to understand and master the subject matter related to the use of } \\
\text { AutoCAD software. }\end{array}$ \\
\hline
\end{tabular}


INTERNATIONAL JOURNAL OF ACADEMIC RESEARCH IN BUSINESS AND SOCIAL SCIENCES Vol.9, No.5, May, 2019, E-ISSN:2222-6990 @ 2019 HRMARS

\begin{tabular}{|l|l|l|}
\hline \multirow{5}{*}{} & A8 & $\begin{array}{l}\text { Attend short courses to help improve the skills of using AutoCAD software in teaching } \\
\text { session. }\end{array}$ \\
\cline { 2 - 3 } & A9 & Attempt to guide poor or weak students to complete the tasks like other students. \\
\cline { 2 - 3 } & A10 & $\begin{array}{l}\text { Refer to the guidelines (syllabus) provided to ensure that the teaching had been } \\
\text { handled accordingly to the standard curriculum requirements. }\end{array}$ \\
\cline { 2 - 3 } & A11 & $\begin{array}{l}\text { Prepare a proper lesson plan according to the syllabus in the provision of teaching aids } \\
\text { to make learning more effective. }\end{array}$ \\
\hline & A12 & Analyze student's achievements for follow-up actions. \\
\hline & T1 & Provide exposure to the teaching strategies that can be applied in the classroom. \\
\hline T2 & Assists in selecting teaching methods that are suitable for the students. \\
\hline T3 & Helps to plan for more effective teaching plans. \\
\hline & T4 & Provide exposure to the use of teaching aids. \\
\hline T5 & Helps to convey the content of the lessons properly and effectively. \\
\hline & T6 & Helps to conduct TnF actively in the class. \\
\hline & T7 & Help teachers to be more creative during TnF. \\
\hline T8 & Helps to underline basic instructions in AutoCAD software. \\
\hline T9 & Increase the skills of using AutoCAD software. \\
\hline T10 & Efficiently helps to produce Orthographic Projections. \\
\hline T11 & Efficiently helps to produce Architectural Drawing. \\
\hline T12 & Efficiently helps to produce Structural Drawing. \\
\hline
\end{tabular}

\section{Discussions and Conclusion}

The aspects of readiness should be measured accordingly and thoroughly. There are four main factors that contribute to this readiness which is the knowledge, skills, attitudes, and training. Through the results of this research, it is hoped that it can provide further insight for the Technical and Vocational Education Division (TVED) to develop and produce an initial course, which is in line with the latest technology to the VC educators before the implementation of any new program is carried out. Additionally, it will also help the administrators to plan beforehand additional activities thoroughly such as co-curriculum activities or assign informal office tasks so that the teachers will have more time to make a preparation before entering the class.

Technical instructors are the most important individuals in the institutes of technical and vocational education. This is because they are the ones that always need to be responsive towards any kind of changes in the industry in order to produce highly skilled graduates in which able to meet and fulfil the requirements of the industry and the future of the country. Their tasks are not only to deliver the knowledge and skills to the students, but they are also responsible in developing the students' interests, abilities, and sharpen their talents. If the instructor is inexperienced, it is difficult to deliver the knowledge and relatable skills, which suits the needs of the industry. Hence, the role and competency of the instructors is very crucial in order to produce skilled workforce in which at the same time is in accordance with the requirements of the country's development. The importance of having well-rounded workforce is that it can help in development of the country. The most appropriate or relevance training curriculum for the instructors must include competency categories, which can help honing the talents of the instructors. 


\section{Acknowledgement}

We wish to express our gratitude to Educational Planning and Research Division, Ministry of Education and Technical and Vocational Education Division for allowing us to conduct this study. Sincerely thanks to the Department of Engineering Technology, Faculty of Technical and Vocational, Universiti Pendidikan Sultan Idris for the opportunity and huge moral support. Thank you to all experts for their assistance and guidance on this study.

\section{Corresponding Author}

\section{Zuraifah Safiee}

Department of Engineering Technology, Faculty of Technical and Vocational, Universiti Pendidikan Sultan Idris, 35900 Tanjong Malim, Perak, Malaysia

Email: zuraifah.s@gmail.com

\section{References}

Ahmat, A. (2016). Pelaksanaan Mata Pelajaran Kemahiran Vokasional di Kolej Vokasional Dalam Kalangan Guru-guru Bukan Opsyen Kemahiran. Tesis Sarjana, Universiti Teknologi Malaysia.

Badri, M., Al Rashedi, A., Yang, G., Mohaidat, J., \& Al Hammadi, A. (2014). Technology readiness of school teachers: An empirical study of measurement and segmentation. Journal of Information Technology Education Research, 13, 257-275.

Aris, B. (2001). Universiti Teknologi Malaysia's teacher education students learning about ICT using ICT. Skudai: Universiti Teknologi Malaysia.

Bonanno, P. (2011). Developing an Instrument to Assess Teachers Readiness for TechnologyEnhanced Learning. In International Conference on Interactive Collaborative Learning (pp. 438-443).

Khalid, I. (2013). Kesediaan Guru Mata Pelajaran Aliran Vokasional Melaksanakan Program School Enterprise di Sekolah Menengah Teknik Zon Selatan. Tesis Sarjana, Universiti Putra Malaysia.

Bunimin, J. (2016). Model Konsep Pembangunan Profesionalisme Tenaga Pengajar Kolej Vokasional Malaysia. Tesis Doktor Falsafah, Universiti Tun Hussein Onn Malaysia.

Kariyev, A., Turganbayeva, B., Slambekova, T., Zheldybayeva, B., \& Kabdualiyeva, A. (2015). Model of Formation of Teacher's Readiness to Learning on The Base of Interactive Methods as The Conditions Of Creation of Students Abilities. In 2nd Global Conference on Psychology Researches (Vol. 190, pp. 353-357). Kazakhstan: Eisevier Ltd.

Kementerian Pendidikan Malaysia. (2015). Malaysia Education Blueprint 2015-2025. Putrajaya: Kementerian Pendidikan Malaysia.

Kopsen, S., \& Anderson, P. (2017). Reformation of VET and Demands on Teacher's Subject Knowledge-Swedish Vocational Teacher's Recurrent Participation in a National CPD Initiative. Journal of Education and Work, 30(1), 69-83.

Pillai, P., \& Shaji. (2017). Analysis of Training Needs of Vocational Trainers in Skill Development- A Case Study From Vhse, Kerala. International Seducation and Research Journal, 3(1), 9-11.

Rohayani, A. H. H., Kurniabudi, \& Sharipuddin. (2015). A Literature Review: Readiness Factors to Measuring e-Learning Readiness in Higher Education. Procedia Computer Science, 59, 230234. 
Hassan, R. A. (2014). Kompetensi Guru Bukan Opsyen yang Mengajar Kemahiran Teknikal di Kolej Vokasional Negeri Pahang. Tesis Sarjana, Universiti Tun Hussein Onn Malaysia.

Simona, G. (2015). Teacher Training for Embedding Life Skills into Vocational Teaching. In The 6th International Conference Edu World 2014 "Education Facing Contemporary World Issues" (pp. 814-819). Romania: Elsevier Ltd. https://doi.org/10.1016/j.sbspro.2015.02.215

Razak, S. K. (2013). Kesediaan Bakal Guru DPLI Terhadap Mata Pelajaran Reka Cipta Untuk Mengajar Di Sekolah Menengah. Tesis Sarjana, Universiti Tun Hussein Onn Malaysia.

Ismail, S. (2012). Kesediaan Guru Terhadap Pelaksanaan Mata Pelajaran Reka Bentuk dan Teknologi (RBT) Sekolah Rendah di Malaysia. Tesis Sarjana, Universiti Tun Hussein Onn Malaysia.

Jaafar, S., Ali, S. (2014). Kompetensi Guru Dalam Pengajaran Amali Teknologi Pembinaan di Kolej Vokasional. Tesis Sarjana, Universiti Tun Hussein Onn Malaysia.

Hamid, W. N. I. (2011). Tahap Keyakinan dan Sikap Guru Terhadap Pengajaran Kemahiran Hidup di Sekolah Menengah Zon Skudai dan Nusajaya, Johor. Tesis Sarjana, Universiti Teknologi Malaysia.

Yagci, M., Sırakaya, D. A., \& Özüdoğru, G. (2015). The Investigation of Attitude and Readiness of Information and Communication Technologies Pre-service Teachers Toward Web Based Learning. Procedia - Social and Behavioral Sciences, 174, 1099-1106.

Harun, Z. N. (2014). Kompetensi Guru Dalam Pengajaran Amali Reka Bentuk dan Teknologi di Sekolah Rendah Daerah Batu Pahat. Tesis Sarjana, Universiti Tun Hussein Onn Malaysia.

Rashid, Z. A. (2016). Tahap Kesediaan Guru Dalam Aspek Pengetahuan Dan Keperluan Latihan Berfokuskan Aplikasi KBAT. Tesis Sarjana, Universiti Tun Hussein Onn Malaysia. 